\title{
The Hydrogen Energy Potential of Solid Waste: A Case Study of Misrata City
}

\author{
Moutaz Benali, Tarek Hamad, Yousif Hamad, Ahmad Belkhair \\ Department of Sustainable and Renewable Energy Engineering, Omar Al-Mukhtar University, El-Beida, Libya \\ Email: moutaz.benali@omu.edu.ly
}

How to cite this paper: Benali, M., Hamad, T., Hamad, Y. and Belkhair, A. (2019) The Hydrogen Energy Potential of Solid Waste: A Case Study of Misrata City. Advances in Biological Chemistry, 9, 45-53. https://doi.org/10.4236/abc.2019.92004

Received: February 19, 2019

Accepted: April 8, 2019

Published: April 11, 2019

Copyright (c) 2019 by author(s) and Scientific Research Publishing Inc. This work is licensed under the Creative Commons Attribution International License (CC BY 4.0).

http://creativecommons.org/licenses/by/4.0/ (c) (i) Open Access

\begin{abstract}
This study presents an overview on solid waste that can be used as a source of bioenergy in Misrata including municipal solid waste (MSW), industrial solid waste (ISW), and healthcare solid waste (HSW) as biomass sources. The management of solid waste and valorization is based on an understanding of MSW's and HSW's composition and physicochemical characteristics. Of MSW's, the results show that organic matter represents $59 \%$ of waste, followed by paper-cardboard $12 \%$, miscellaneous $10 \%$, plastic $8 \%$, metals $7 \%$ and glass $4 \%$. While HSW comprised of $72 \%$ general healthcare waste (non-risk) and $28 \%$ hazardous waste. The average general waste composition was: $38 \%$ organic, $24 \%$ plastics, and $20 \%$ paper. The potential of hydrogen energy produced from biogas in Misrata including MSW, and other organic feedstock such as food and kitchen waste, animal wastes, clover and reeds, wheat residues, barley residues, HSW and sewage waste as biomass sources. The total potential hydrogen output is estimated to be around 10,265 tons per year.
\end{abstract}

\section{Keywords}

Hydrogen, Solid Waste, Waste to Energy, Biomass Sources, Bioenergy

\section{Introduction}

Recent publications have shown that hydrogen derived from renewable energy sources is a practical solution for a substantial reduction of greenhouse gas emissions. Hydrogen can serve as a sustainable energy provider while leaving a zero-carbon footprint at the point of use and more recently, provide a design for the Combined Heat, Hydrogen, and Power (CHHP) system [1] [2]. Those studies were based on utilizing the local organic resources to generate biogas using anaerobic digestion process. Those studies also provided a mass balance calculation to estimate the amount of hydrogen delivered from the organic feedstock 
collection. The other studies investigated the energy potential of feedstock like maize stalks, dairy products and dry bread, discussed the effects of the organic and inorganic phase composition of biomass [3] [4] [5] [6] [7].

One of these researches provides comparisons between a wide-variety of biomass [5]. The results from other studies are expected to be utilized for the initial classification or prediction of the future advanced sustainable processing of biomass to biofuels [8] [9] [10]. It provides a comprehensive collection of potential feedstock types for production of biogas through anaerobic digestion [9]. This paper also provides typical biogas yields and suggests that anaerobic digestion may be the optimum mode of biogas production, mainly due to the associated advantages, such as, the ability to treat high moisture content feedstock, a straight-forward process of biogas production, and the robustness of the method, even at a small scale level. The final methane yields of substrates and the available experimental procedures are used to achieve the results. Other papers examined the influence of various parameters on the biochemical methane production determination, which allows demonstrating the lack of uniformity in the data reported [10] [11]. It suggests that the bioconversion of food waste into energy, in terms of, say, hydrogen, is economically viable [11]. It suggests that an effective mode of collection of food waste, coupled with these available technologies would provide a practical mode of conversion of food waste to energy. One of the studies investigates the biogas yield of the anaerobic digester for a variety of feedstock types [12]. It considered liquid and solid-state anaerobic digester, mainly depending on the feedstock type. It also suggests that the anaerobic digestion process is robust in treating a variety of feedstock types, including individual feedstock and their mixtures. The feedstock considered by the author includes MSW; forest and wood industry wastes including bark, chips, sawdust, hardboard dust, mud from paper industry and raw cork; agricultural waste, such as crop silage and livestock manure; industrial waste from coal mining, lumber mills, or other facilities; and even the gases that are naturally produced within landfills. The study also provides the equivalent energy content from these feedstock types.

This paper extends this initial effort and provides a comprehensive list of organic feedstock types that are available in the Misrata city and achieved only through a ready availability of low cost biogas for the production of hydrogen, eventually used as a vehicular fuel providing a study that focuses on the energy potential of a variety of agricultural byproducts and organic wastes, which may be used in the anaerobic digestion plants to produce biogas.

\section{Aim of the Study}

This study aimed to estimate the composition of MSW, HSW and ISW in Misrata city. And also utilizes the available data on the biomass content and determines the hydrogen production capability, thus enabling a comprehensive production of hydrogen energy potential. 


\section{Place of Study}

Misrata city show in Figure 1 is located in the north-western corner of the municipality of Sirt in a plain bordered to the north by the Mediterranean Sea, to the east by Sirt Municipality, to the south by Bani-Walid, from the west to Zliten with a coast of $125 \mathrm{~km}$, Tripoli to $210 \mathrm{~km}$ and Benghazi from $825 \mathrm{~km}$, Located on the line of length 15.09 east and latitude 32.38 north, with an area of about $55.2 \mathrm{~km}^{2}$.

\section{Background}

Temperatures for Misrata city in the summer can reach $51^{\circ} \mathrm{C}$ during the day; through they are typically closer to $38^{\circ} \mathrm{C}$. The average annual temperature is approximately $21.5^{\circ} \mathrm{C}$. The mean annual rainfall is $90 \mathrm{~mm}$. Misrata's population has nearly doubled over the last 10 years. Misrata youth represent more than $50 \%$ of the current population. This situation places a great deal of pressure on energy demands, food supplies, and even the environment by increasing the generation of waste and residues. For the last two decades, Misrata had depended on fossil fuels, petroleum, and natural gas for its income, energy, industrialization, and development. Although some efforts have been made to diversify the sources of income, to a large extent, fossil fuels have continued to play a major role in the country's economy. Unfortunately, the fossil fuels available in this area are becoming depleted Figure 2. A total dependence on oil and gas can lead to serious consequences. Out of the renewable energy sources, such as solar, wind, and wastes, conversion of waste feedstocks to $\mathrm{H}_{2}$. Its useful products such

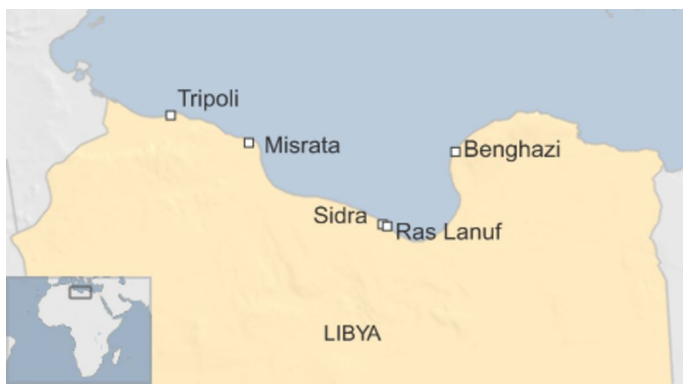

Figure 1. Misratah city (Source google map).

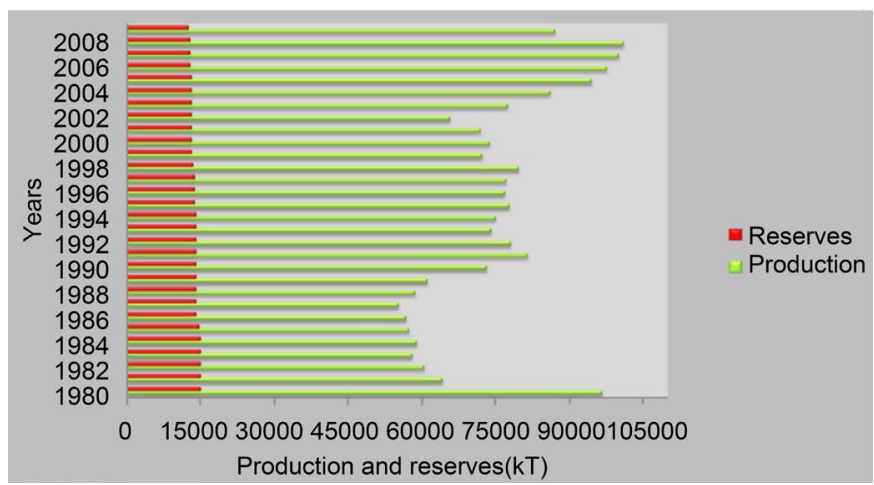

Figure 2. Fossil fuel reserves and production of Libya vs. Time [9]. 
as electricity, heat, reduce fossil fuel usage, and greenhouse gas emissions at the Misrata. Solid waste is one of most important sources of biomass potential in Misrata. Biomass is a by-product from human activities that is characterized by negative impacts that may affect man and the environment when disposed of in an inappropriate way. This paper investigates whether or not solid waste can be used as a source of bioenergy in Misrata.

\section{Resource Assessment}

Classifications of solid wastes are proposed here according to the origin wastes: MSW, ISW, and HSW.

\subsection{Municipal Solid Waste}

MSW is generally defined as waste collected by municipalities or other local authorities. It includes mainly household (domestic waste), commercial, and institutional wastes (generated from shops and institutions). These wastes are generally in solid or semi-solid form. It can be classified as biodegradable waste that includes food and kitchen waste, green waste, and paper (can also be recycled); recyclable materials such as paper, glass, bottles, cans, metals, certain plastics, etc.; inert waste such as construction and demolition wastes, dirt, rocks, and debris; composite waste which includes waste clothing, tetra packs, and waste plastics such as toys; domestic hazardous waste (also called "household hazardous waste"); and toxic waste like medication, e-waste, paints, chemicals, light bulbs, fluorescent tubes, spray cans, fertilizer and pesticide containers, batteries, and shoe polish.

MSW will be different. In general, the composition of MSW in Misratah with six major categories of waste was identified: organic matter, paper-cardboard, plastics, glass, metals, and others Table 1 .

Organic matter was the predominant category and represented $59 \%$ of waste collected. The other categories were represented as follows: paper-cardboard (12\%), plastic (8\%), glass (4\%), metals (7\%), and others (10\%) Figure 3.

Table 1. Waste composition category.

\begin{tabular}{|c|c|}
\hline Waste category & Waste components \\
\hline Organic matter & $\begin{array}{l}\text { Waste from foodstuff such as food and vegetable refuse, fruit skin, stem of green, } \\
\text { corncob, leaves, grass, and manure }\end{array}$ \\
\hline Paper & $\begin{array}{l}\text { Paper, paper bags, cardboard, corrugated board, box board, newsprint, } \\
\text { magazines, tissue, office paper, and mixed paper (all papers that do not fit into } \\
\text { other categories) }\end{array}$ \\
\hline Plastic & $\begin{array}{l}\text { Any material and products made of plastics such as wrapping film, plastic bag, } \\
\text { olythene, plastic bottle, plastic hose, and plastic string }\end{array}$ \\
\hline Glass & $\begin{array}{l}\text { Any material and products made of glass such as bottles, glassware, light bulb, } \\
\text { and ceramics }\end{array}$ \\
\hline Metals & $\begin{array}{l}\text { Ferrous and non-ferrous metal such as tin can, wire, fence, knife, bottle cover, } \\
\text { aluminum can and other aluminum materials, foil, ware and bi-metal }\end{array}$ \\
\hline Others & $\begin{array}{l}\text { Materials from leather, rubber, textile, wood, and others such yard waste, tires, } \\
\text { batteries, large appliances, nappies/sanitary products, medical waste, etc. }\end{array}$ \\
\hline
\end{tabular}




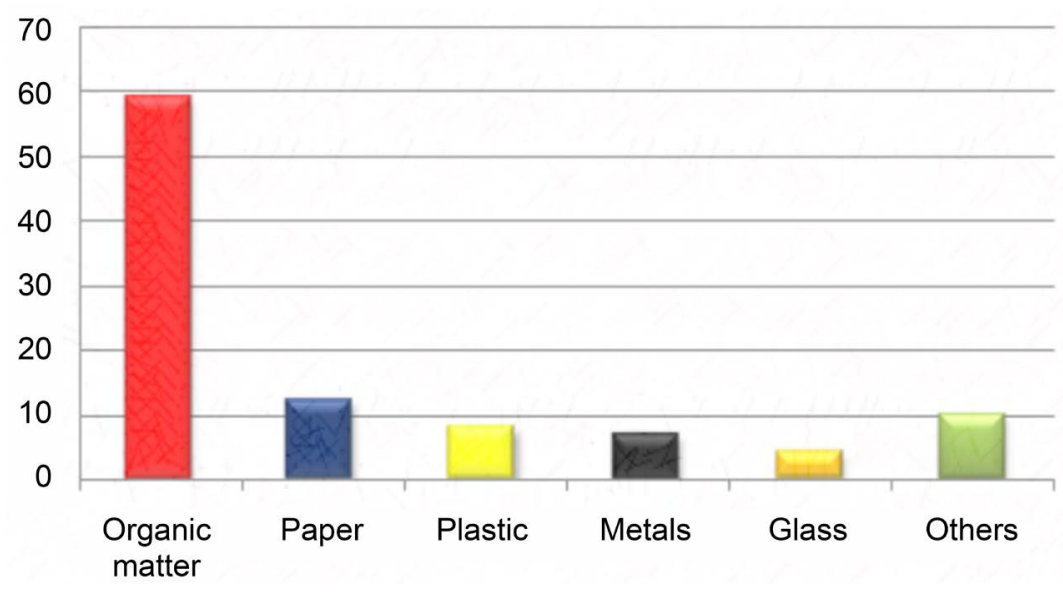

Figure 3. MSW composition survey in Misrata.

\subsection{Industrial Solid Waste}

The overall generation of industrial waste, including non-hazardous and inert industrial wastes in Misratah, is 748,800 tons per year. This type of waste is generated from the following:

- Steel, metallurgical, mechanical, and electrical industries, which are the predominant sectors (50\%);

- Building materials, ceramics, and glass industries (50\%);

- Chemicals, rubber, and plastic industries (2\%);

- Food processing, tobacco, and match industries (29\%);

- Textiles, hosiery, and confection industries (10\%);

- Leather and shoes industries (1\%); and

- Wood, paper, printing industries (3\%).

The hazardous waste which includes waste oil, waste solvents, ash, cinder, and other wastes with hazardous nature (such as flammability, explosiveness, and causticity) generated amounts to 63,720 tons/year Figure 4 .

\subsection{Healthcare Solid Waste}

HSW include plastic syringes, animal tissues, bandages, cloths, and so forth. This type of waste is produced by the treatment, diagnosis, and immunization of humans and/or animals at hospitals, veterinary and health related research facilities, and substances medical laboratories. These HSWs contain infectious waste, toxic chemicals, and heavy metals. Several may contain that are radioactive. Misrata contains 5 hospitals ( 3 governmental hospitals and 2 private hospitals) with a total of 2000 beds. HSWs reach 2.6 ton/day, of which $72 \%$ is general waste and $28 \%$ is hazardous waste Figure 5.

The qualitative analysis of general waste Figure 6 determined organics as the primary component (38\%), followed by plastics (24\%). The high plastic content is due to the widespread use of disposables rather than reusables for various purposes (e.g. bottles, packaging materials and bags used for food). Paper had the third highest percentage (20\%). 


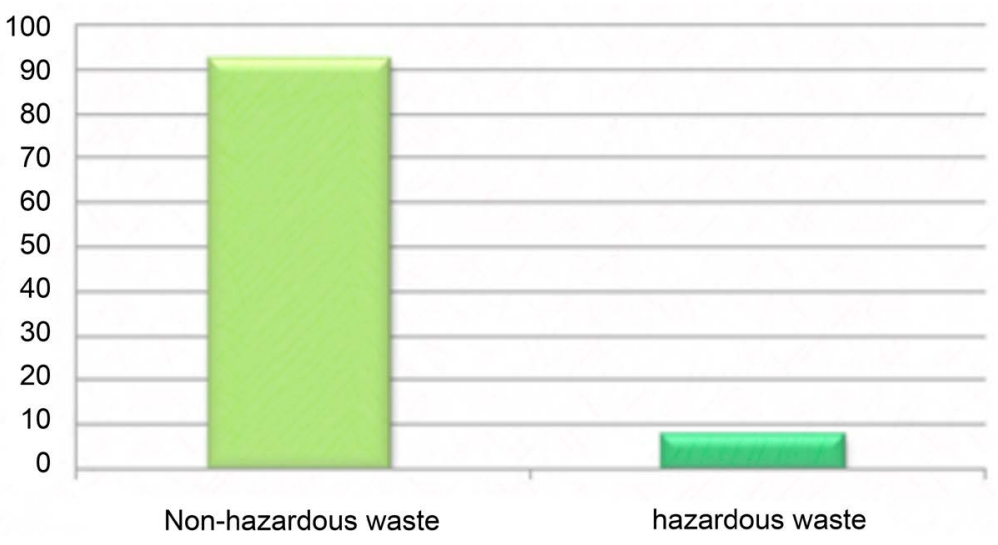

Figure 4. ISW composition survey in Misrata.

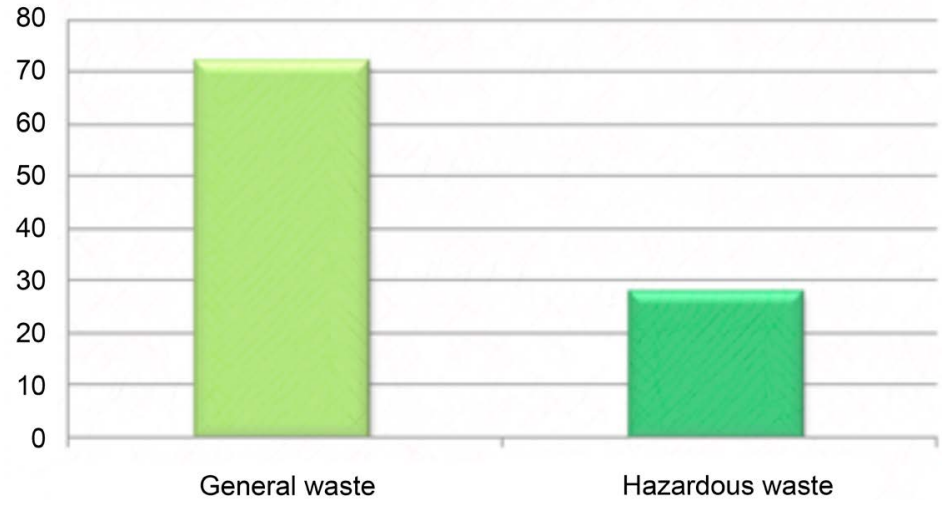

Figure 5. HSW composition survey in Misrata.

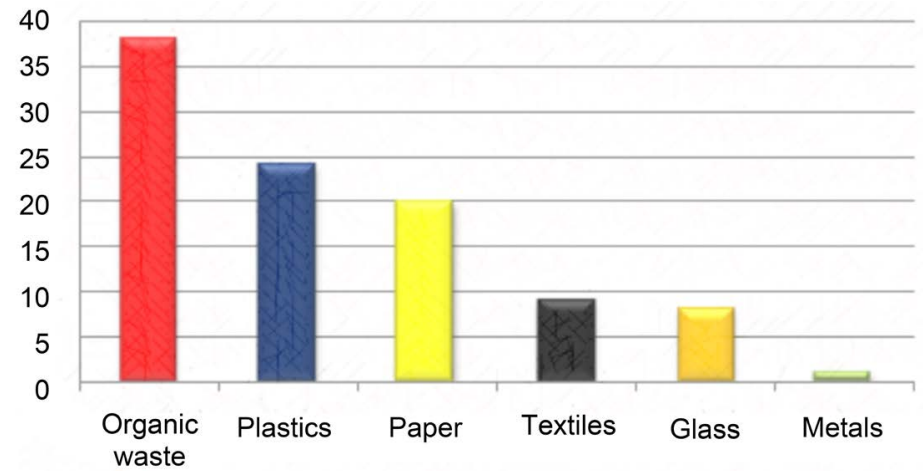

Figure 6. Average general healthcare waste composition in Misrata.

\section{The Mechanism of Hydrogen Extraction}

The feedstock is collected and then pretreatment and transported to the anaerobic digester where bacteria destroy the organic matter in the oxygen absence and then produce the biogas gas. The biogas is then purified from the impurities in a unit pressure swing adsorption (PSA) to obtain pure methane. The competition rules specify that all methane entering the direct fuel cell (DFC) unit is internally reformed and converted to hydrogen and that only 75\% (the fuel utilization rate) of the $\mathrm{H}_{2}$ produced is reacted at the anode to produce electricity. It al- 
so specifies that $1 / 4$ of the $25 \%$ hydrogen produced is stored (Hydrogen is an energy carrier, not an energy source) Figure 7.

\section{Feedstock Source Identification}

They can be classified as biodegradable wastes that include the following: Animal wastes, MSW, clover and reeds, wheat residues, barley residues, HSW, and sewage waste.

\section{Energy Conversions}

After identifying the potential organic feedstock types that are readily available in the area of Misrata, their equivalent methane production capacity of each feedstock types except sewage waste due to small factor (gas production/quantity) was determined. Previous published works proved to be of great resource in this part of the study. Using the equivalent methane production capacity of each feedstock types, with the anaerobic digestion process, the total methane capacity of feedstock was determined. Using the works the equivalent hydrogen production capacity of each feedstock type was determined. The summary of all the calculations is presented in Table 2.

The qualitative analysis of feedstock Figure 8 determined animal wastes as the

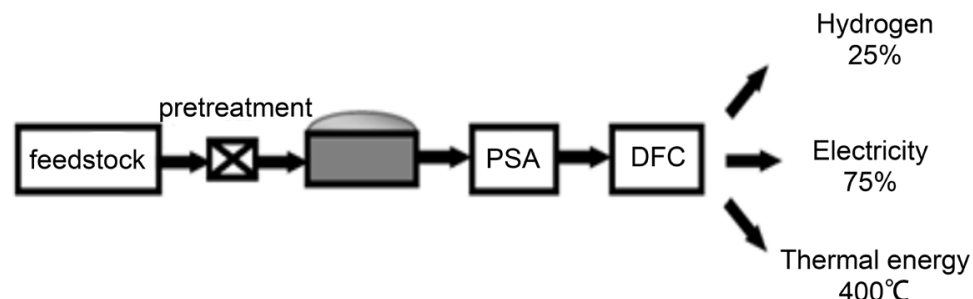

Figure 7. Mechanism of hydrogen extraction.

Table 2. Energy conversions at each potential facility.

\begin{tabular}{|c|c|c|c|c|c|}
\hline \multirow{2}{*}{$\begin{array}{l}\text { Type of } \\
\text { feedstock }\end{array}$} & \multirow{2}{*}{$\begin{array}{l}\text { Quantity } \\
\text { ton/yr. }\end{array}$} & \multirow{2}{*}{$\begin{array}{c}\text { Gas } \\
\text { production/quantity }\end{array}$} & \multicolumn{2}{|c|}{ Equivalent methane production ${ }^{a}$} & \multirow{2}{*}{$\begin{array}{l}\text { Production } \\
\text { of hydrogen } \\
\text { ton/yr. }\end{array}$} \\
\hline & & & $\mathrm{m}^{3} / \mathrm{yr}$. & ton/yr. & \\
\hline Animal wastes & 54,198 & $\begin{array}{c}0.62 \mathrm{~m}^{3} \mathrm{CH} 4 / \mathrm{kg} \\
\mathrm{VS}^{\mathrm{b}}\end{array}$ & $33,602,760$ & $22,177.8$ & $5,544.46$ \\
\hline MSW & 73,219 & $\begin{array}{l}0.22 \mathrm{~m}^{3} / \mathrm{kg} \\
\mathrm{ODS}^{\mathrm{b}}\end{array}$ & $16,108,180$ & $10,631.4$ & $2,657.8$ \\
\hline $\begin{array}{l}\text { Clover and } \\
\text { reeds }\end{array}$ & $20,320.4$ & $\begin{array}{c}0.36 \mathrm{~m}^{3} \mathrm{CH} 4 / \mathrm{kg} \\
\mathrm{VS}^{\mathrm{b}}\end{array}$ & $7,315,344$ & 4828.13 & 1207 \\
\hline Barley residues & 9415.3 & $\begin{array}{c}0.538 \mathrm{~m}^{3} \mathrm{CH} 4 / \mathrm{kg} \\
\mathrm{VS}^{\mathrm{b}}\end{array}$ & $5,065,431$ & 3343.2 & 835.8 \\
\hline $\begin{array}{l}\text { Wheat } \\
\text { residues }\end{array}$ & 198.8 & $\begin{array}{c}0.34 \mathrm{~m}^{3} \mathrm{CH} 4 / \mathrm{kg} \\
\mathrm{VS}^{\mathrm{b}}\end{array}$ & 67,592 & 44.6 & 11.15 \\
\hline HSW & 219 & $\begin{array}{c}0.22 \mathrm{~m}^{3} / \mathrm{kg} \\
\mathrm{ODS}^{\mathrm{b}}\end{array}$ & 48,180 & 31.79 & 7.9 \\
\hline & Total & & $62,208,404.46$ & $41,057.588$ & $10,264.397$ \\
\hline
\end{tabular}

${ }^{a}$ Annual average. ${ }^{b}$ Methane yield. Assumption $85 \%$ collection rate. Organic Dry Solid (ODS). Volatile Solid (VS). 


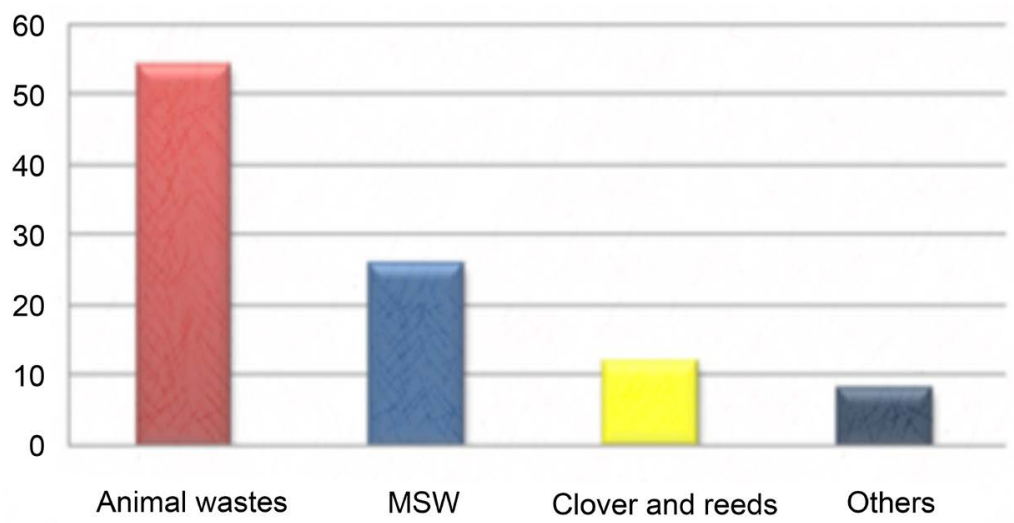

Figure 8. Hydrogen yields of various feedstock types.

primary component (54.02\%), followed by MSW (25.89\%) and clover and reeds $(11.76 \%)$. The high animal wastes content is due to the large quantity. The total estimated hydrogen production for the Misrata will be about 10,265 tons per year.

\section{Conclusion}

This study presents an overview on solid waste that can be used as a source of bioenergy in Misrata including MSW, ISW, and HSW as biomass sources. The management of solid waste and valorization is based on an understanding of MSW's composition and physicochemical characteristics. The paper identified all of the sustainable indigenous feedstock types for the area of Misrata, along with their distribution and energy potential. Energy from waste is not a new concept, but it is a field that requires serious attention. The dependence of Misratah on fossil fuels will be reduced, and significantly reducing both pollution and greenhouse gas emissions. Solid waste can be used as an energy source in Misrata. Finally, the total potential hydrogen output is estimated to be around 10,265 tons per year. The results generated in this paper provide a conclusive evidence of a sustainable hydrogen energy future.

\section{Acknowledgements}

The researches would like to thank the Department of Sustainable and Renewable Energy Engineering, Omar Al-Mukhtar University, El-Beida Libya for their financial support.

\section{Conflicts of Interest}

The authors declare no conflicts of interest regarding the publication of this paper.

\section{References}

[1] Hamad, T.A., Agll, A.A., Hamad, Y.M., Bapat, S., Thomas, M., Martin, K.B., et al. (2014) Study of a Molten Carbonate Fuel Cell Combined Heat, Hydrogen and Power System. Energy, 75, 579-588. https://doi.org/10.1016/j.energy.2014.08.020 
[2] Hamad, T.A., Agll, A.A., Hamad, Y.M., Bapat, S., Thomas, M., Martin, K.B., et al. (2013) Study of a Molten Carbonate Fuel Cell Combined Heat, Hydrogen and Power System: End-Use Application. Case Studies in Thermal Engineering, 1, 45-50. https://doi.org/10.1016/j.csite.2013.09.001

[3] Wang, C., Dong, Y., Cheng, H., He, Y., Ye, J. and Zhou, H. (2013) Physicochemical Properties of Lacquer Berries and Decolorization of Lacquer Wax by Physical Adsorption and UV Irradiation. Advances in Biological Chemistry, 3, 329-337. https://doi.org/10.4236/abc.2013.33037

[4] Hamad, T.A., Agll, A.A., Hamad, Y.M., Bapat, S., Thomas, M., Martin, K.B., et al. (2014) Hydrogen Production and End-Uses from Combined Heat, Hydrogen and Power System by Using Local Resources. Renewable Energy, 71, 381-386. https://doi.org/10.1016/j.renene.2014.05.054

[5] Vera, D., Jurado, F., De Mena, B. and Schories, G. (2011) Comparison between Externally Fired Gas Turbine and Gasifier-Gas Turbine System for the Olive Oil Industry. Energy, 36, 6720-6730. https://doi.org/10.1016/j.energy.2011.10.036

[6] Hamad, T.A., Agll, A.A., Hamad, Y.M., Bapat, S., Thomas, M., Martin, K.B., et al. (2014) Study of Combined Heat, Hydrogen and Power System Based on a Molten Carbonate Fuel Cell Fed by Biogas Produced by Anaerobic Digestion. Energy Conversion and Management, 81, 184-191.

https://doi.org/10.1016/j.enconman.2014.02.036

[7] Benali, M., Hamad, T., Belkhair, A. and Hamad, Y. (2019) Investigating the Use of Combined Hydrogen, Heat and Power System for Omar AL-Mukhtar University Campus. Advances in Biological Chemistry, 9, 31-44. https://doi.org/10.4236/abc.2019.91003

[8] Demirbas, A. (2008) Importance of Biomass Energy Sources for Turkey. Energy Policy, 36, 834-842. https://doi.org/10.1016/j.enpol.2007.11.005

[9] Hamad, T.A., Agll, A.A., Hamad, Y.M. and Sheffield, J.W. (2014) Solid Waste as Renewable Source of Energy: Current and Future Possibility in Libya. Case Studies in Thermal Engineering, 4, 144-152. https://doi.org/10.1016/j.csite.2014.09.004

[10] Odlare, M., Arthurson, V., Pell, M., Svensson, K., Nehrenheim, E. and Abubaker, J. (2011) Land Application of Organic Waste-Effects on the Soil Ecosystem. Applied Energy, 88, 2210-2218. https://doi.org/10.1016/j.apenergy.2010.12.043

[11] Yu, M., Muy, S., Quader, F., Bonifacio, A., Varghese, R., Clerigo, E., et al. (2013) Combined Hydrogen, Heat and Power (CHHP) Pilot Plant Design. International Journal of Hydrogen Energy, 38, 488-4888. https://doi.org/10.1016/j.ijhydene.2013.02.006

[12] Bouckaert, S., Assoumou, E., Selosse, S. and Maïzi, N. (2014) A Prospective Analysis of Waste Heat Management at Power Plants and Water Conservation Issues Using a Global TIMES Model. Energy, 68, 80-91. https://doi.org/10.1016/j.energy.2014.02.008 